\title{
Ortner's syndrome: a rare cause of hoarseness
}

\author{
Obinna Okoye, ${ }^{1}$ Nwabundo Anusim, ${ }^{1}$ Andrew Shon, ${ }^{2}$ Aibek E Mirrakhimov ${ }^{1}$
}

1 Department of Internal Medicine, Saint Joseph Hospital, Chicago, Illinois, USA ${ }^{2}$ Department of Radiology, University of Illinois at Chicago, Chicago, Illinois, USA

\section{Correspondence to} Dr Aibek E Mirrakhimov, amirrakhimov1@gmail.com

\section{DESCRIPTION}

An 81-year-old man with a medical history of hypertension, hyperlipidaemia, chronic kidney disease, coronary artery disease presented to the ear, nose and throat (ENT) physician with symptoms of hoarseness of voice which had persisted for over 6 weeks. Otolaryngoscopy was negative for obvious malignancy and he was diagnosed as having left vocal cord paralysis with a suspicion of thoracic aorta pathology. CT angiogram showed type B dissecting aortic aneurysm with aortic diameter of $4.7 \mathrm{~cm}$ at the level of the aortic arch (figure 1) and $5.3 \mathrm{~cm}$ dilation about $8 \mathrm{~cm}$ superior to the diaphragm with signs of dissection (figure 2). Consensus by cardiology and cardiac surgery services was to continue medical management as he was not a surgical candidate on account of chronicity of the findings, age and associated comorbidities.

Vocal cord paralysis is one major group of pathological processes that could cause hoarseness. ${ }^{1}$ Major causes of unilateral vocal cord paralysis include: iatrogenic from surgery around the recurrent laryngeal nerve (36.5\%) malignancy (18.4\%) and idiopathic (18.5\%). Aortic aneurysms accounted for only $0.3 \%$ of cases. ${ }^{2}$ Left recurrent laryngeal nerve loops under the arch of the aorta and the longer course of the left recurrent laryngeal nerve around the aortic arch may account for the higher incidence of left vocal palsy when compared to the right. ${ }^{3}{ }^{4}$ In general, voice changes persisting for a period of 2-4 weeks requires ENT evaluation and the most important reason to visualise the larynx in hoarseness is to exclude malignancy. ${ }^{1}$

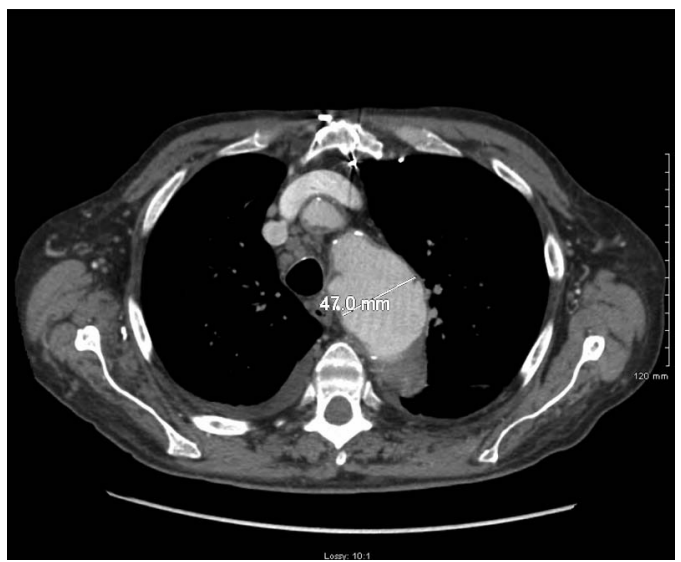

Figure 1 A CT scan of the chest showing dilation of the aortic arch.

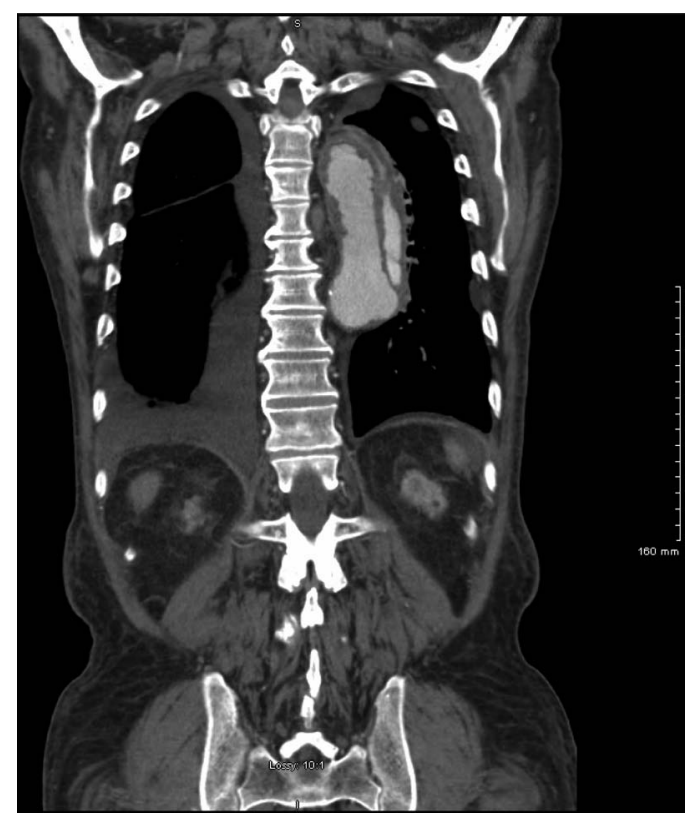

Figure 2 CT showing dilation of thoracic aorta with a formation of intimal flap and double lumen consistent with aortic dissection.

\section{Learning points}

- Voice changes persisting for a period of 2-4 weeks requires ENT evaluation.

- It is important to consider cardiovascular causes of unilateral vocal cord paralysis especially after excluding common causes such as malignancy and recent local surgery.

- Chronic type B dissections in older individuals with reduced life expectancy can be managed medically.

Competing interests None.

Patient consent Obtained.

Provenance and peer review Not commissioned; externally peer reviewed.

\section{REFERENCES}

1 Mau T. Diagnostic evaluation and management of hoarseness. Med Clin North Am 2010;94:945-60.

2 Rosenthal LH, Benninger MS, Deeb RH. Vocal fold immobility: a longitudinal analysis of etiology over 20 years. Laryngoscope 2007;117:1864-70.

3 Bickle IC, Kelly BE, Brooker DS. Ortner's syndrome: a radiological diagnosis. Ulster Med J 2002;71:55-6.

4 Glazer HS, Aronberg DJ, Lee JK, et al. Extralaryngeal causes of vocal cord paralysis: CT evaluation. AJR Am J Roentgenol 1983;141:527-31.
To cite: Okoye 0 Anusim N, Shon A, et al. BMJ Case Rep Published online: [please include Day Month Year] doi:10.1136/ bcr-2013-010016 


\section{Images in...}

Copyright 2013 BMJ Publishing Group. All rights reserved. For permission to reuse any of this content visit http://group.bmj.com/group/rights-licensing/permissions.

BMJ Case Report Fellows may re-use this article for personal use and teaching without any further permission.

Become a Fellow of BMJ Case Reports today and you can:

- Submit as many cases as you like

- Enjoy fast sympathetic peer review and rapid publication of accepted articles

- Access all the published articles

- Re-use any of the published material for personal use and teaching without further permission

For information on Institutional Fellowships contact consortiasales@bmjgroup.com

Visit casereports.bmj.com for more articles like this and to become a Fellow 